\title{
МОВНІ ДЕВІАЦІЇ ІНТЕРФЕРЕНТНОГО ХАРАКТЕРУ В СИСТЕМІ СУЧАСНОЇ УКРАЇНСЬКОЇ МОВИ
}

Мішеніна Т. М. Мовні девіації інтерферентного характеру в системі сучасної української мови.

У статті здійснено аналіз явища інтерференції, розмежовано інтерфереми i суперінтерфереми (суржикові компоненти) як різновиди мовних девіацій. Уживання інтерферем на рівні семантичної модифікації спричиняє уживання слів у невластивому значенні в системах російської й української мов. Мовні девіації, спричинені помилками перекладу (калькуванням), неоднозначністю семантичних реляцій, лексичних сигніфікативних значень, становлять суржикові ненормативні компоненти.

Ключові слова: інтерференція, інтерферема, суржиковий компонент, мовна норма, кодифікація, семантична модифікація, мовна девіація, нормативність мовлення, правильність мовлення, чистота мовлення.

Мишенина Т. М. Языковые девиации интерферентного характера в системе современного украинского языка.

В статье сделан анализ явления интерференции, разграничены интерферема и суперинтерферема (суржиковые компоненты). Употребление интерферем на уровне семантической интерференции детерминируют функционирование слов с неприсущим им значением в системах русского и украинского языков. Языковые девиации, обусловленные ошибками перевода (употребление кальки), неоднозначностью семантических реляций, лексических сигнификативных значений, составляют суржиковые ненормативные компоненты.

Ключевые слова: интерференция, интерферема, суржиковый компонент, языковая норма, кодификация, семантическая модификация, языковая девиация, нормативность речи, правильность речи, чистота речи.

Mishenina T. M. Language deviation interferential character in the system of modern Ukrainian language.

The article provides an analysis of the phenomenon of interference, and delineated interferema, superinterferema (components "surzhiks"). Drinking interference level semantic interference dictate the functioning of words with their extrinsic value systems in Russian and Ukrainian languages. Language deviation due to translation errors (use of tracing paper), semantic ambiguity of correlations, lexical significative values constitute deviant components "surzhiks".

Key words: interference interferema, component "surzhiks" linguistic norm, codification, semantic modification, linguistic deviation, normativity speech, correct speech, purity of speech.

Мовні девіації, що виникають у результаті порушення норм, суттєво гальмують процес адекватного сприймання інформації реципієнтом. Суспільна функція мовної норми полягає в обов'язковому 
дотриманні кодифікованої мовної норми. Порушення норми є суспільно небезпечним явищем, оскільки неодмінно фіксуються у сфері свідомого чи підсвідомого, спричиняють формування неправильних лінгвостереотипів і тим самим заважають виробленню й закріпленню літературних норм у соціумі.

Проблемою девіативності опікувалися у своїх дослідженнях Ю. Апресян [1], В. Дєвкін [6], В. Виноградов, Т. Булигіна, А. Шмельов [15], О. Падучева [11]. На сучасному етапі розвитку лінгвістичної думки створено концепції, за якими: помилки досліджуються задля удосконалення мовлення, підвищення рівня грамотності мовців (Н. Бабич, М. Волощак, Н. Непийвода) [3; 5; 10]; аналізуються у практичній стилістиці як джерело кодифікації норм (Н. Ботвина, О. Пономарів) [4; 13]; осмислюються причини виникнення помилок та досліджуються шляхи їх усунення й попередження (В. Мамушин, Л. Покровський) [9; 12].

На сучасному етапі формування редагувального апарату актуальним $€$ з'ясування лінгвістичної сутності таких понять, як мовна, мовленнєва й немовна помилки; орфографічна, лексична, морфологічна, словотвірна, синтаксична, стилістична помилки; семантична модифікація лексем; росіянізми; інтерферема тощо; систематизація мовних девіацій і створення конструктивної їх класифікації; здійснення лінгвістичного аналізу текстів освітніх і наукових видань.

Мета роботи полягає в розробленні типології мовних девіацій інтерферентного характеру шляхом виявлення й систематизації їх структурно-семантичних особливостей. Систематизацію мовних девіацій було здійснено на основі лінгвістичного аналізу текстів освітніх та наукових видань, які було редаговано на правах літературного редактора.

Явище міжмовної інтерференції як один із типів мовної взаємодії, що відбувається в межах і внаслідок мовного контакту, розглядається поряд із такими типами мовної взаємодії, як запозичення, калькування й асиміляція.

Під калькою (фр. каlguе - копія) розуміється нова лексему, створена питомими мовними засобами за зразком іншої мови [2, с. 73]. При калькуванні копіюється структура чи внутрішня форма 3 адаптованим перекладом iї компонентів. Як засіб номінації калькування є доцільним тоді, коли для певного поняття, явища немає назви в рідній мові. Наприклад: укр. недолік є калькою рос. недочёт, 
займенник - калькою лат. pronomen [13].

На відміну від запозичення і калькування, що розглядаються як нормативні мовні елементи, інтерференцію (від лат. inter - між, взаємно і ferens (ferentis) - мимовільне перенесення, накладання ознак однієї мови на іншу в практиці двомовної людини [7, с. 70]) слід пов'язувати 3 негативним аспектом мовної взаємодії, оскільки наслідком цього процесу є відхилення від норми. «Конкретним мовним виявом інтерференції є інтерферема [7, с. 11]»- лінгвоодиниця, утворена шляхом буквального перекладу з урахуванням фонетиковимовних норм мови, що зазнає впливу. Не мотивовані номінативно, інтерфереми не стають фактом мови, оскільки функціонують як паралельні, але не синонімічні до наявних засоби словесного вираження. Інтерфереми є небезпечним денаціоналізуючим явищем, тому що витісняють з ужитку питомі мовні одиниці.

Інтерфереми, відмінні структурними і фонетичними особливостями, зафіксовано в таких текстових фрагментах: Сьогоднішнє покоління (нормативний варіант - сучасне) виховується не на текстовій, а на візуальній інформації будь-якого типу. Студенти, які вивчають іноземні мови сьогодні (нормативний варіант- нині), краще сприймають, опрацьовують $i$ запам'ятовують саме візуально поданий матеріал (мультимедійні навчальні програми ци учбові (нормативний варіант навчальні) фільми). Візуалізація учбової інформації сприяє більш інтенсивному засвоєнню матеріалу, орієнтуючи студента (курсанта) на пошук системних зв 'язків і закономірностей.

Сполучення сьогоднішнє покоління є калькуванням із російської мови сегодняшнее поколение. В українській мові літературним уживанням є сполучення сучасне покоління, оскільки лексема сьогодні реалізує денотат «у конкретно названий темпоральний період», натомість сучасність охоплює більш тривалий темпоральний відтинок, передбачає епоху. Зважаючи на окреслене вище російський варіант «сегодня» правильно розуміти в системі української мови як нині, противагою $є$ український варіант «сьогодні» на позначення доби, у період перебігу якої відбуваються події. Контекст наведених прикладів переконує в тому, що «сьогодні» $\epsilon$ порушенням стилістичної норми, оскільки функціональним є варіант «нині», що містить у семантичній структурі денотат «у певний добовий період», нівелюючи відтінок «у період етапу розвитку суспільства; епохи».

Ненормативна одиниця учбовий співвідноситься 3 російським (C) Т. М. Мішеніна, 2014. 
прикметником «учебный». Словотвірна модель інтерфереми учбовий відповідає моделі, за якою творяться інші слова в українській мові: основа іменника + суфікс -ов-. Водночас у лексико-семантичній системі іменники «учоба, учба»є ненормативними, тому від них неможливо утворити прикметник. Сучасні лексикографічні праці донині містять окремі одиниці, що виникли в результаті штучного наслідування російської мови. 3-поміж численних інтерферем, унесених до словників, фіксуємо прикметник учбовий, що подається як абсолютний синонім до слова навчальний [16, с. 1310]. Наведена вище мотивація дає змогу вважати нормативним лише прикметник навчальний, функціонування якого не суперечить структурним можливостям мови.

Прикметник учбовий наявний і в ненормативній абревіатурі вуз та похідних утвореннях (наприклад вузівський), які характеризуються значною повторюваністю в освітніх і наукових матеріалах. Продуктивна інтерферема абревіатурного типу витіснила 3 ужитку українські еквіваленти - внз, виш, взо. Тому нині рекомендовано усувати з текстів названу інтерферему, натомість повертати до активного використання питомі одиниці: Питання формування готовності майбутніх офічерів у прочесі вузівської підготовки розглядається у прачях науковців вишівської. Розкрито особливості довузівської ци післявузівської підготовки педагогічних кадрів - до вишівської й післявишівської.

Варто розмежовувати пароніми приводити / призводити, де перший варіант передбачає результат цілеспрямованої дії «приводити до певного пункту»; другий - зумовити певні негативні результати. Лексична мовна норма передбачає вживання лексеми спричиняти, зумовлюти на позначення наслідку, результатів дії, процесу: Відповідно, головним завданням компетентнісного підходу є така організація навчального прочесу, яка дає змогу забезпечити спроможність випускника відповідати новим запитам ринку. Це призводить до того, щцо пред'являються нові вимоги до підготовки інженерів, де стратегічним завданням є готовність до професійної діяльності.

У наведеному фрагменті спостерігаємо калькування від російського варіанта предьявлять, українським варіантом в наведеному контексті $€$ лексема висувати. Зауважимо, що російський варіант передбачає в контексті предьявлять документи український - подавати документи.

Відповідно, наведений фрагмент слід редагувати в такий спосіб: Усе че зумовлює (спричиняє) висунення нових вимог.

Серйозні випробування логічного емпіризму на стійкість привели 
до фундаментальної переоцінки теорії та методологї̈ досліджень, які суперечили позитивістській традиції досліджень, а також метафізичним та методологічним припущенням дослідників у галузі спеціальної освіти - зумовили фундаментальну переоцінку.

Російський варіант привести в українській мові має також відповідник навести, реалізуючи значеннєвий відтінок «презентувати, засвідчити»: Автором приведено методику формування в курсантів готовності до професійної діяльності, яка реалізується у процесі використання сукупності форм - наведено приклад методики; наведено авторську методику.

Розмежовуються в українській мові варіанти існуючий / чинний, оскільки перший варіант означає «бути в реальності», другий - «такий, що має юридичну силу, тобто чинність»: Професійна підготовка курсантів здійснюється через уюее існуючу професійну підготовку офічера-вихователя - у межах чинної професійної підготовки.

Спостерігаємо порушення лексичної мовної норми на рівні реалізації значення «бути чим, виконувати певну функцію, мати статус, становити щзо»: бути, становити. У наведених реченнях слід інтерферему виступати редагувати відповідно: У сучасному світі соціальна справедливість виступає метою $i$ основою розвитку соціальної держави, а отже, ціннісною основою суспільства, орієнтованого на добробут усіх його членів - становить мету; 3 а результатами анкетування, здійсненого науковцем, найбільш ефективним засобом уведення нових слів для досліджуваних виявилося введення слів до змістовного контексту, також контекст виступив базисом для встановлення значення невідомого слова - становив базис; Кожний профіль передбачає сформованість компетенцій, які виступають базовою основою для виконання дочільності дій в умовах як світового, так $і$ військового часу - що становлять базову основу; Концептуальною основою нашого підходу виступило поєднання двох загальновідомих методів: методу візуалізації та методу складання міні-оповідань - стало.

В українській мові синтаксична конструкція бути чим; як певний використовується зі значенням «виконувати функцію» (рос. выступать в качестве): Узявши за основу тему «Crimes: Autotheft» з підручника Career Paths English: Police, який пропонується курсантам 1-го курсу в якості базового для бакалаврів спеиіальностей «Правознавство» та «Правоохоронна діяльність», ми розробили міні-оповідання для 


\section{СТРУКТУРА І СЕМАНТИКА МОВНИХ ОДИНИЦЬ}

первинної активації та подальшого запам'ятовуання таких англомовних слів та фраз - як базовий; Такий підхід ефективно застосовується в якості інтерактивної платформи для навчання в колективі та через колектив, оскільки забезпечує активну мовленнєву взаємодію всіх учасників навчального процесу, тобто інтерактивність - як інтерактивна платформа.

Якщо йдеться про функцію, виконувану особами, використовується синтаксична конструкція «виступати за кого, ким» (рос. действовать в качестве кого), пор.: действовать в качестве посередника - виступати за посередника; действовать в качестве свидетеля - виступати за свідка; действовать в качестве истиа виступати позивачем [19]. Редагування потребують речення До умов формування готовності майбутніх офіцерів до професійноӥ діяльності віднесено: визначення рівня підготовки курсантів $i$ спеціальна підготовка офіцуерів, які не мають педагогічної освіти, які виступають в якості основних суб'єктів освітнього процесу; розроблення спеціальних технологій навчання військово-професійной nідготовки - які виступають за основних суб'єктів.

В українській мові нормативній одиниці бути відповідає російський варіант выступать: Таким середовищем виступає навчальна група, факультет, ВНЗ ... - є навчальна дисципліна.

Українському відповіднику становити / бути відповідає російський являть собой, тому редагування подібних варіантів подання передбачає розмежування значення «являтися у часопросторі» $\mathrm{i}$ «становити певну характеристику»: Процес візуалізації являє собою звернення мисленнєвого змісту у наочний образ, який може бути розгорнутий $i$ може слугувати опорою адекватних мисленнєвих та практичних дій - становить.

Нормативний варіант виокремити відповідає російським уживанням виділити (підкреслити), виокремити (відмежувати, сформувати в певну групу, систему тощо). У реченні редагування потребує пропонований варіант виділений, ужитий у невластивому значенні: Автором виділені психолого-педагогічні умови формування комплексної готовності майбутнього офіцера до професійної діяльності, які передбачають: визначення рівня підготовки навчаючих; спеціальну підготовку майбутніх офіцерів, які не мають педагогічної освіти - виокремлені.

Типовим порушенням лексичної норми $є$ послуговування варіантом включати, відповідного російському включать. Водночас в українській 
мові лексема включати є некодифікованою. Натомість значеннєві відтінки, що утворюють семантичне ядро лексеми російського варіанта включати, реалізовані у варіантах охоплювати (системність понять), передбачати (прогнозування результатів діяльності), містити (склад).

3 огляду на викладений вище коментар речення слід редагувати так: В аналізованій праці готовність до професійної діяльності майбутніх офіцеерів розуміється як інтегративна особистісна якість, яка включас систему знань, умінь і навичок із фахових дисциплін яка охоплює; На основі інтегративного підходу готовність включає мотиваційну готовність - передбачає; Професійна підготовка $\epsilon$ невід 'ємним компонентом єдиної системи освіти, а ї̈ зміст включає поглиблене засвоєння основ $i$ технологій виду працуі - передбачає; Готовність до того або іншого виду діяльності - це иілеспрямоване вираження особистості, щуо включає ї̈ переконання, погляди, мотиви, почуття, вольові й інтелектуальні якості, знання, навички, вміння, установки, налаштованість на певну поведінку - охоплює.

Наголосимо на тому, що російський варіант синтаксичної конструкції включать в себя у значенні «передбачати процес; певні види дії тощо» в системі української кодифікації детермінує використання конструкції з дієсловом передбачати: Психологічна підготовленість включас в себе: а) глибоке знання наук, певний рівень розвитку; б) підготовленість у певній галузі знань; в) обізнаність у професійній діяльності, знання вимог спеціальності до особистих якостей $i$ здібностей; г) уміння вчитися; д) морально-психологічну підготовленість - передбачає; Цілі дослідження включають детальний опис середовищза дослідження, чітке формулювання дослідницького процесу та узагальнення іниих складників навчання - передбачають.

Якщо йдеться про особистісне утворення, розглядуване у психологічній науці, то нормативними будуть уживання охоплювати / містити, передбачаючи складники внутрішнього світу: Наведено різні визначення ї̈ сутності: наявність здібностей, як якість особистості, як ставлення, як синтез властивостей особистості, як особливий психічний стан особистості, який включає в себе переконання, погляди, ставлення, мотиви - охоплює, містить.

У реченні Отже, психологічна готовність забезпечує динамічне включення людини в діяльність, так само як і наступну надійність $i$ ефективність усієї ї стратегї - інтерферему включення (рос. включение) редагуємо як залучення до, оскільки 3 контексту 
констатуємо значення «залучення до процесу».

Інтерферема решить в українській мові реалізує значення «віднайдення розв’язків галузевих задач / завдань», натомість якщо йдеться про проблему, проблемну ситуацію, мету, слід надавати перевагу варіанту розв'язати.

У реченнях Рефлексивна функція виникає, коли є труднощуі і стоїть питання щуодо вирішення даної проблеми; Автори зазначених досліджень започаткували вирішення проблеми формування лексичної компетенції, але, нині в умовах нових освітніх та мультимедійних технологій і методів, можливості роботи на етапі первинної активації англомовної лексики суттєво розиирились - слід редагувати виділене сполучення як «розв’язання окресленої (порушеної) проблеми».

Функціонування лексеми труднощі передбачає валентну сполученість із дієсловами усувати, розв'язувати: Саме коли особистість вирішує свої труднощі, відбувається ї становлення як індивідуума та подальший розвиток у професійній діяльності усуває, розв’язує труднощі.

Лексема следующиий в українській мові передбачає ряд лексем, які реалізують значеннєві відтінки: наступний (у ряді однорідних предметів. Понять, чинників тощо), такий (певний, конкретний), подальиий (у темпоральному значенні, реалізований після констатованої точки відліку).

У такий спосіб редагування речень з аналізованою інтерферемою передбачає таке: Аналізуючи літературу, ми виокремили наступні складники, які свідчать про сформованість готовності майбутнього офіцера до виховання військовослужбовців - такі складники; Уміння використовувати результати аналізу роботи майбутніх офіцерів у процесі планування наступної роботи - подальшої роботи.

В українській мові лексеми схожий і подібний мають значеннєві відтінки, які окреслюють їх функціональні властивості. У першому випадку ідеться про подібність, наближеність за формою, у другому за змістом. У текстових фрагментах спостерігаємо порушення мовної норми: Офіцеер повинен уміти розрізняти схожсість і різницю $у$ споріднених і схожсх явищуах - розрізняти спільні і відмінні риси ... у подібних явищах; Дати відповідь на питання: Чим схожсі тексти технічної літератури, створювані украӥнською та англійською мовами? - подібні тексти.

Прикладом семантичної модифікації під час використання 
інтерферем може слугувати використання лексеми область 3 ненормативним значенням «певна сфера виробництва, науки тощо» [20; 21; 22; 24, с. 326-327]: область * застосування, область * інформації, область * науки. Лексична помилка зумовлена впливом російської мови, де семантичне поле слова «область» ширше, ніж українського відповідника, оскільки названа лексема в українській мові може вживатися лише із значенням «а) частина якої-небудь території (країни, держави, материка); б) адміністративно-територіальна одиниця; в) $y$ математиці - скінченна частина простору або поверхні». Семантиці наведеного контексту відповідає нормативна лексема - галузь.

У межах лексичної норми виокремлюємо нормативні слововживання [17; 18; 24, с. 326-327; 25, с. 399]: 1) галузь «певна сфера виробництва, науки тощуо»: галузь інформачиї, галузь наук; 2) область «а) частина якої-небудь території (країни, держави, материка); б) адміністративно-територіальнаодиниця; в) у математиці - скінченна частина простору або поверхні»: висотна область тепла, Миколаӥвська область, кліматична область, прикордонна область; 3) зона «а) простір, у якому поширюється будьяке явище, шуо характеризується певними рисами, особливостями; б) у біологї - місче розташування якого-небудь внутрішнього органа або тварини»: низькотемпературна зона, зона заток, сейсмононебезпечна зона; 4) ділянка «окрема частина поверхні, площуі, простору, яку використовують з якою-небудь метою або відокремлюють за якоюнебудь ознакою»: потилична ділянка, ділянка пам'яті, електронна ділянка; 5) дільниця «окрема частина простору суспільного призначення»: виборча дільниця; 6) царина «сфера діяльності, коло знань, уявлень»: царина науки.

Наведені текстові фрагменти засвідчують порушення лексичної мовної норми: Нині в освітній сфері на периий план виходять не окремі філософські та педагогічні теорії, пов'язані лише концептуально, а комплексні філософсько-освітні концеепиї, в переважній більшості випадків зорієнтовані на конкретну педагогічну практику - освітній галузі; Психологічна підготовленість передбачає: а) глибоке знання наук, певний рівень розвитку; б) підготовленість у певній сфері знань; в) обізнаність у професійній діяльності, знання вимог спеціальності до особистих якостей $i$ здібностей; г) уміння вчитися; д) морально-психологічну - галузь знань; B. Вундт (W. Wundt) був творичем методологічних досліджень у 
галузі психологіï, сфері, щзо перебуває в тісних взаємозв'язках з освітніми дослідженнями. Розробленням наукових методів дослідження в близькоспорідненій області-педагогічній психології, ми завдячуємо Е. Торндайку (E. Thorndike) - галузь освітня.

Семантична структура російського іменника «отношение» відповідає низці значень в українській мові, які реалізують кілька лексем. Нечітка диференціація семантики лінгвоодиниць у мовах, що контактують, зумовлює появу лексичних помилок: ринкові стосунки*; газові стосунки*, відномення* до людини, економічні відношення* між країнами. Під впливом інтерференції іменник стосунки зазнав семантичної модифікації, оскільки набув значення, властивого слову відносини, що вживається як термін у суспільно-економічній, дипломатичній, виробничій сфері або ж використовується на позначення зв'язків між країнами, соціально-економічними й політичними об'єднаннями тощо; іменник відношення реалізує значення, властиве лексемі ставлення (той або інший характер поводження з ким-, чим-небудь). Нормативними будуть такі поєднання: ринкові відносини, газові відносини, економічні відносини між крайнами; ставлення до людини. Іменник стосунки вживається тоді, коли мають на увазі взаємини між людьми, членами якогось колективу; зв’язки, контакти взагалі. Цьому суперечать анормативи на зразок негармонійні відносини*, міжособистісні відносини*.

Редагування текстових фрагментів передбачає таке: Специфіка реалізації одиницьь семантико-синтаксичного рівня у текстах технічної літератури; темо-рематичні відносини в текстах технічної літератури - відношення (взаємозв'язки); Дослідники розглядають готовність як певний функціональний стан, психологічну й сочіальну установку відносин, щзо характеризують поведінку особистості - на гармонійні стосунки та взаємозв'язки; Суттєвим $\epsilon$ те, щуо психологічна готовність $\epsilon$ універсальною передумовою ефективності не тільки будь-якої діяльності, але й інших характеристик психічнӧ̈ життєдіяльності людини - $і ̈$ спілкування й відносин з іншими людьми, адекватності ї̈ відносин до самої себе - стосунків з іншими людьми; ставлення до самої себе.

Інтерферема соединение відповідає українським поєднання (частин мови); з'єднання (те, щзо з'єднує; місце, де щзо-небудь з'єднують або з'єднали); сполука (у хімї - речовина, у якій атоми одного чи різних елементів з'єднані між собою за допомогою певного 
типу хімічного зв'язку; у математиці - сукупності, утворені з даних елементів у заданому числі); сполучення (операція реляційної алгебри) [16, с. 364; 1177]. Нормативним буде таке вживання: Формування професійних умінь може бути ефективнішим, якщо залучити студентів до навчально-пізнавальної діяльності як репродуктивного, так $i$ проблемного проблемно-пошукового $i$ творчого характеру в їхньму сполученні, з урахуванням поетапної системи навчання - у поєднанні; Конкретний стан готовності до дії визначається сполученням факторів, щуо характеризують різні рівні $і$ сторони готовності - поєднанням.

В українській мові розмежовуються лексеми ряд і низка: у першому випадку ідеться про особи, у другому - про перелік однорідних понять, предметів, явищ, установ тощо. Наприклад: Готовність входить до ряду основних складників психічної діяльності людини - низки; Практика психологічної готовності спортсмена, льотчика-випробувача, полярника або космонавта обов'язково передбачає як певну програму формування психологічної готовності до майбутньої діяльності, так у ряді випадків й оцінку рівня досягнутого результату - низці.

Соціокультурні чинники зумовлюють використання в межах лексичної дистрибуції лексеми межах зі значеннєвим актуалізатором «допустима норма вияву явища»: Інічіативи в рамках інклюзивної реформи вимагали емпіричного аналізу, заснованому на знаннях, отриманих в результаті досліджень $i$ не покладатись на необтрунтовані переконання чи почуття - у межах.

В умовах постійного контактного білінгвізму виникають одиниці, на утворенні яких різною мірою позначається дія інтерференційних чинників. Відповідно такі мовні елементи зазнають впливу адаптації до законів української мови. Найбільшої адаптації до граматичних чи словотворчих особливостей зазнають кальки, що виникають унаслідок запозичення внутрішнього плану нового слова та його моделі для реалізації на власному мовному грунті. Оскільки кваліфікація кальок у мовознавчій літературі є неоднозначною, то ненормативні одиниці, що виникають шляхом копіювання структурних, фонетичних особливостей лексеми і через неврахування наявності питомого слова, нами номінуються інтерферемами. Найменша адаптація до законів української мови характерна для суржикових утворень, якими $є$ російські елементи, що вживаються в обрамленні української 


\section{СТРУКТУРА I СЕМАНТИКА МОВНИХ ОДИНИЦЬ}

граматичної системи, а також на тлі українських фонетичних норм $\mathrm{i}$ становлять гібридні форми [2; 3]. Ці субстрати $є$ наслідком змішування мовних систем у свідомості білінгва, чи так званої суперінтерферениії (суржикові компоненти - суперінтерферемами), що в українському соціумі номінується суржиком. Фактично гібридні одиниці повністю відтворюють російську вимову, тобто виникають у результаті транскрибування російської лексеми. Причому запозичений елемент може зазнавати лише мінімальних змін на фонетичному рівні. В умовах масової українсько-російської двомовності на рівні однієї особи 3 неоднаковою компетенцією в обох мовах досить поширена практика структурного калькування будови лексичних одиниць та семантичного запозичення з однієї мови в іншу [1;2].

Наводимо дієслівні термінологічні конструкції [подано за 19], під час послуговування якими прогнозованим $є$ порушення мовної норми (приклади дібрано шляхом опитування носіїв української й російської мов - білінгвів). Дієслівні сполучення згруповано відповідно до вживання головного слова в російській та українській мовах: 1) отклонять / відхиляти: отклонить пропозицию - відклонити пропозицію*; 2) отменять / скасовувати: отменять приказ - відмінити наказ*, отменить решение - відмінити рішення*; 3) ущемлять / обмежувати, уражати, ображати: ущеелять права- ущемляти права* (обмежувати), ущемлять самолюбие - ущемляти самолюбство * уражати (ображати) самолюбство; 4) получить / дістати (отримати): получить отказ - получити відмову*, получить урок - получити урок*, получить признание - получити визнання*, получить выговор - получити догану*, получать отставку - получати відставку*; 5) поступить / вчинити: поступить благородно - поступити благородно* (вчинити иляхетно); 6) принимать / брати: приймати участь*; 7) приступить, вступить, открывать / розпочати: приступить к работе - приступити до роботи*, вступить в борьбу - вступити в боротьбу*, приступить $\kappa$ обсуждению - приступити до обговорення*, открывать деятельность - відкривати діяльність*, открывать заседание - відкривати засідання*; 8) сопоставлять, совпадать / зіставляти, збігатися: сопоставлять позиции - співставляти позиції (зіставляти), совпадають точки зрения - співпадають думки (збігаються); 9) подвергаться, испытывать, понести, вынести, набраться / зазнавати: подвергаться влиянию - підвергатись впливу*, испьтыввать страдание - іспитувати страждання*, испьтывать бедствие - іспитувати біду*, понести 
убытки - понести збитки*, набраться бедь - набратись лиха*, вынести унижение - винести приниження *; 10) приобретать, получить / набувати: приобретать опьт - пріобретати (получити) досвід*, приобретать в собственность - пріобретати (получити) у власність *, получить образование - получити освіту*; 11) вносить, предъявлять / подати: вносить в комиссию - вносити в комісію*, вносить на утверждение - вносити на затвердження*, предъявлять документы пред’являти документи*, предъявлять вексель ко взысканию пред'являти вексель до суду*; 12) преподать, предоставить / надати: предоставить возможность - предоставити можливість * (надати), предоставить выбор - предоставити вибір* (надати), предоставить место - предоставити місце (надати), преподать руководящие указания - преподати керівні вказівки* (надати керівні вказівки).

Лінгвістичний аналіз текстів освітніх і наукових видань засвідчує, що рівень мовної грамотності сучасної освітньої й наукової продукції не відповідає ідеальній моделі мовної поведінки в науковій й освітній галузях як професійного комунікатора, оскільки в матеріалах констатовано мовні девіації інтерферентного характеру.

Виокремлено критерії виявлення мовних помилок під час редагування освітніх i наукових текстів. Описано критерій відповідності / невідповідності лінгвоодиниці нормам української літературної мови, критерій функціональної доцільності.

Здійснено спробу розролення протипомилкового апарату редактора, що містить дані про типові ненормативні мовні одиниці, спрогнозовано потенційні помилки інерферентного характеру.

Зважаючи на визначальну роль освіти й науки у формуванні соціокультурних цінностей, нагальною видається потреба укладання рекомендацій із розв'язання проблем мовних девіацій, подання належної теоретичної інтерпретації природи помилки, інтегрованого осмислення аналізованого явища, а також узагальнення досвіду його вивчення.

\section{Література}

1. Апресян Ю. Д. Языковые аномалии: типы и функции / Ю. Д. Апресян // Res Philologica. - M., 1990. - C. 50-71.

2. Ахундзянов Э. М. Двуязычие и лексико-семантическая интерференция / Э. М. Ахудзянов. - Казань, 1972. -234 с.

3. Бабич Н. Д. Основи культури мовлення / Н. Д. Бабич. - Львів : Світ, 1990. - 232 с.

4. Ботвина Н. Офіційно-діловий та науковий стилі української мови : [навчальний посібник] / Н. Ботвина. - К. : Артек, 1999. - 264 с.

5. Волощак М. Неправильно - правильно: довідник 3 українського (ㄱ Т. М. Мішеніна, 2014. 


\section{СТРУКТУРА І СЕМАНТИКА МОВНИХ ОДИНИЦЬ}

слововживання: за матеріалами засобів масової інформації / М. Волощак. - К. : Видавничий центр «Просвіта», 2000. - 128c.

6. Девкин В. Д. Очерки по лексикографии / В. Д. Девкин. - М. : Прометей, 2000. $395 \mathrm{c}$.

7. Єрмоленко С. Я. Українська мова : Короткий тлумачний словник лінгвістичних термінів / за ред. С. Я. Єрмоленко. - К. : Либідь, 2001. - 224 с.

8. Кривошеєва О. С. Питання культури української мови у періодичних виданнях української діаспори США і Канади : автореф. ... дис. канд. філол. наук / О. С. Кривошеєва. - Х., 1996. - 18 с.

9. Мамушин В. Е. О характере и причинах речевых ошибок и об «ошибках контроля» / В. Е. Мамушин // Русский язык в школе. - 1990. - № 1. - С. 45-49.

10. Непийвода Н. Ф. Сам собі редактор: Порадник 3 української мови / Н. Ф. Непийвода. - К. : Укр. книга, 1998. - 238 с.

11. Падучева Е. В. Тема языковой коммуникации в сказках Льюиса Кэрролла / Е. В. Падучева // Семиотика и информатика. - М. : ВИНИТИ, 1982. - Вып. 18. - С. 76-79.

12. Покровский Л. Л. Ложная этимология как одна из причин орфографических ошибок / Л. Л. Покровский // Русский язык в школе. - 1981. - № 2. - С. 41-46.

13. Пономарів О. Культура слова : Мовностилістичні поради : [навчальний посібник] / О. Пономарів. - К. : Либідь, 1999. - 240 с.

14. Шмелев А. Г. Введение в экспериментальную психосемантику / А. Г. Шмелев. - M., 1983. - $158 \mathrm{c}$.

\section{Список використаних джерел}

1. Антоненко-Давидович Б. Д. Як ми говоримо / Б. Д. Антоненко-Давидович. - К. : Вид. дім «КМ Akademia», 1994. - 254 с.

2. Великий тлумачний словник сучасної української мови / уклад. і голов. ред. В. Т. Бусел. - К. : Ірпінь : ВТФ «Перун», 2001. - 1440 с.

3. ДСТУ 3891-99. Безпека у надзвичайних ситуаціях. Терміни та визначення основних понять.

4. Інтелектуальна власність : словник-довідник / за заг. ред. О. Д. Святоцького, В. С. Дроб'язка : у 2-х т. - Т. 1. - К. : Ін Юре, 2000. - 356 с.

5. Калашник В. С. Українсько-російські синтаксичні паралелі : Труднощі перекладу / В. С. Калашник, Ж. В. Колоїз. - Харків : Прапор, 2003. - 112 с.

6. Моргунюк В. С. Зауваження щодо опрацювання державних стандартів 3 науково-технічної термінології / В. С. Моргунюк / АН України, Ін-т проблем міцності : преп. - К., 1993. - 32 с.

7. Тлумачний словник-довідник з автоматизації, телемеханізації та використання обчислювальної техніки для працівників газової промисловості. Основні терміни : близько 4000 термінів ; за заг. ред. М. Д. Гінзбурга, 3. П. Осінчука, Б. І. Педька. Харків, 1997. - $536 \mathrm{c}$.

8. Тугаєнко-Сєряк С. М. Довідник службовця / С. М. Тугаєнко-Сєряк. - К. : A.C.K., 2000. $-416 \mathrm{c}$.

9. Російсько-український словник з інформатики та обчислювальної техніки 3 покажчиком українських термінів / уклад. : В. Я. Карачун, Г. Г. Гульчук, О. О. Карачун, Ю. З. Прохур. - К. : Рось, 1994. - 362 с.

10. Російсько-український словник наукової термінології : Біологія, хімія, медицина / С. П. Вассер, І. О. Дудка, В. І. Єрмоленко та ін. - К. : Наук. думка, 1996. - 660 с. 
11. Російсько-український словник наукової термінології : Математика. Фізика. Техніка. Науки про Землю і Космос / В. В. Гейченко, В. М. Завірюхіна, О. О. Зеленюк та ін. - К. : Наук. думка, 1998. - 892 с.

12. Словник труднощів української мови: близько 15000 слів / Д. Г. Гринчишин, А. О. Капелюшний, О. М. Пазак та ін. ; за ред. С. Я. Срмоленко. - К. : Рад. шк., 1989. - 336 с.

Стаття надійшла до редакиії 20.07.2014 p. 